\title{
A Unified Cloud Computing Model towards Developing 'E-learning as a Service' based Education System
}

\author{
Shah Murtaza Rashid Al \\ Masud \\ Faculty of Computer Science \\ and Information Systems \\ Najran University \\ Najran, Saudi Arabia
}

\begin{abstract}
E-learning is the use of computer, electronic device, mobile and communication devices in some way to provide training, just-in-time-information, guidance from experts, and educational or learning material among learners. E-learning facilitates and enables learners to learn anytime and anywhere. E-learning systems usually require many hardware and software resources to electronically transfer skills and knowledge. Many education institutions do not have the resources and infrastructure needed to run top e-learning solutions and cloud computing is the best solution. Cloud computing is growing rapidly in almost every sector including education and learning process with its promising infrastructure, platform and applications. In this paper the author studied and analyzed the challenges and scopes of cloud computing environment that will be helpful to build a reliable, cost effective and scalable education system, namely e-learning as a service. In this paper the author has proposed a fundamental and unified cloud computing model which is obliging both for vendors, clients, users, professionals, academicians, and researchers involved in development and enlargement of cloud computing services and solutions in education system.
\end{abstract}

\section{General Terms}

Distributed System, Cloud Computing

\section{Keywords}

Cloud Computing, Education System, E-learning, Education Institutions

\section{INTRODUCTION}

The increasing rate of cloud adoption, services and implementations per year in all around the world is very rapid and remarkable. Due to this important reason the overall behavior and functionaries of cloud computing (CC) are changing every day which influence the architecture, taxonomy of CC, and its services. Many hardware and software industries, such as IBM, Intel, Microsoft, Cisco, as well as other Internet technology industries, including Google and Amazon, Security Company, such as Semantic, knowledge groups and even several businesses, also those not technically oriented, want to explore the possibilities and benefits of $\mathrm{CC}$ are joining the development of cloud services [1]-[9]. Although there are huge scopes in developing, implementing, and updating $\mathrm{CC}$ but there is a lack of standardization of cloud computing services [3]-[4], [10], which makes interoperability when working with multiple services or migrating to new services difficult.
The NIST (National Institute of Standards and Technology) proposed the following definition of cloud computing: "Cloud computing is a model for enabling convenient, on-demand network access to a shared pool of configurable computing resources (e.g., networks, servers, storage, applications, and services) that can be rapidly provisioned and released with minimal management effort or service provider interaction" [11]. This cloud model promotes availability.

Currently three service models are being differentiatedSoftware as a Service (SaaS), i.e. online applications, such as web-based email; Platform as a Service (PaaS), which allows customers to deploy their own applications, and Infrastructure as a Service (IaaS), which provides, for example, processing power or storage [12]. Service models of CC recognize and specify the components of cloud computing that are providing basic knowledge underpinning management and implementation of the cloud spectrum and environment.

Cloud computing scenario in education system, the beneficiary, such as universities, e-learning centers, education service providers, just need services and they do not need to undergo the challenges posed by technology, administration and implementation in computerization. Technologically challenging tasks of designing, implementing and maintaining a Data Center/Server, Databases, and Application etc are all eliminated and is left to such service providers of information technology (IT) industry. With education service providers 'elearning as a service', distance education, online education system looking at automating processes at lower cost and higher gains $\mathrm{CC}$ which can act as an ideal platform in the education system based IT space. A number of departments could share infrastructure with large number of systems linked together towards providing e-learning system in higher education. By this pooling the education institutions automatically reduce the cost and increase utilization. The resources are delivered only when they are required. This also means real-time availability of instructors' information for students, learners and other support services personnel like community members from any internet enabled device. Though some models are existed to support education and elearning services, but still system faces many limitations like: capacity building, integration of prevailing education system, promotion of inter-operability using universal standards, cost, and e-learning observatory.

This paper generally draws attention to the application of cloud computing in e-learning environment which is valued for students, instructors and service providers to achieve the course objective. In this paper the author proposed a complete, extended, and granular structure, nature, benefits of 
Volume 72-No.7, May 2013

$\mathrm{CC}$ service model as a platform for e-learning environment that will help CC service providers, users, and also academia, researchers, professionals, stakeholders of IT as well as enterprise to provide e-learning services in academic environment. A short comparative study of different issues directly related to $\mathrm{CC}$ based education and e-learning systems and services are also studied and analyzed in order to address and find the proper way to find problems and get solutions.

This paper is organized as follows: Section II Major entities and characteristics in E-learning system. Section III Benefits, risks, and limitations of cloud computing in 'E-learning as a Service' based education System. Section IV Cloud computing taxonomy towards building a unified model, Section V Proposed unified cloud computing model for education system. Section VI Advantages of using this proposed model in education sector Section VII Existing Cloud Computing Supports in Education System and finally Section VIII concludes the paper.

\section{MAJOR ENTITIES AND CHARACTERISTICS IN E-LEARNING SYSTEM}

E-learning is an internet-based learning process is using to improve the efficiency of education. E-learning in education system is developed as distributed applications using internet technology to initiate, plan, analyze, design, implement, select, manage, support and extend learning. The architecture of a disseminated e-learning system includes software components, like the client application, an application server, a database server and the necessary hardware components such client computer or users, communication infrastructure and servers and service providers as shown in Figure 1.

Today e-learning is extensively used on different educational levels such as continuous education, company trainings, academic courses, and community services. Education institutions need resources and infrastructure to run top elearning solution. There are various e-learning features, benefits, limitations and solutions from open source to commercial as presented in Table 1. There are at least two entities involved in an e-learning system: the students and the teachers. Major benefits include expediency and portability, cost and selection, elasticity or flexibility, higher maintenance, broader collaboration and association and global opportunities.

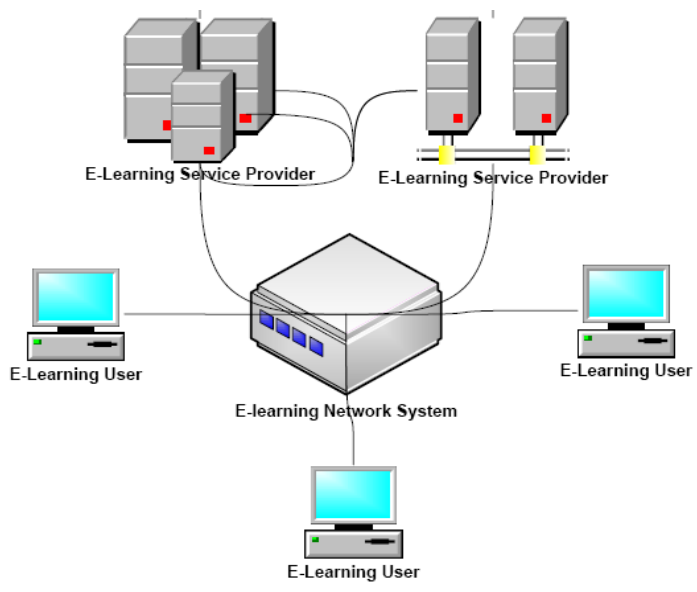

Figure 1: E-learning environment
Table 1: Features, benefits and major entities in e-learning system

\begin{tabular}{|c|c|}
\hline \\
\hline Features & Benefits \\
\hline $\begin{array}{l}\text { Learning or education is self- } \\
\text { motivated and a speedy or } \\
\text { rapid process that provides } \\
\text { students a possibility to } \\
\text { speed up or slow down as } \\
\text { necessary. }\end{array}$ & $\begin{array}{l}\text { Expediency and } \\
\text { portability: } \\
\text { - Courses are accessible } \\
\text { on your schedule } \\
\text { - Online learning does not } \\
\text { require physical } \\
\text { attendance } \\
\text { - Learning is self-paced } \\
\text { (not too slow, not too } \\
\text { fast) } \\
\text { - You're unbound by time } \\
\text { - courses are available } \\
\text { 24/7 } \\
\text { - You're unbound by } \\
\text { place - study at home, } \\
\text { work, or on the road } \\
\text { - Read materials online or } \\
\text { download them for } \\
\text { reading later }\end{array}$ \\
\hline $\begin{array}{l}\text { Self-directed learning } \\
\text { permits students to choose } \\
\text { contents and tools } \\
\text { appropriate to their differing } \\
\text { interests, needs, knowledge } \\
\text { and skill levels }\end{array}$ & $\begin{array}{l}\text { Cost and Selection: } \\
\text { - Choose from a wide } \\
\text { range of courses to meet } \\
\text { your needs } \\
\text { - Degree, Vocational, and } \\
\text { Certificate programs } \\
\text { - Continuing Education } \\
\text { - Individual courses } \\
\text { - Wide range of prices to } \\
\text { fit your budget } \\
\text { - Go back to school to get } \\
\text { a degree, learn a new } \\
\text { skill, learn a new craft, } \\
\text { or just have fun! } \\
\text { - From art to zoology you } \\
\text { can do it all online in a } \\
\text { price range to fit your } \\
\text { budget. }\end{array}$ \\
\hline $\begin{array}{l}\text { Contains multiple learning } \\
\text { styles using a variety of } \\
\text { deliverance methods or } \\
\text { mechanisms geared to } \\
\text { different learners }\end{array}$ & $\begin{array}{l}\text { Flexibility and } \\
\text { Elasticity: } \\
\text { - Online learning } \\
\text { accommodates your } \\
\text { preferences and needs - } \\
\text { it's student-centered } \\
\text { - Choose instructor-led or } \\
\text { self-study courses } \\
\text { - Skip over material you } \\
\text { already know and focus } \\
\text { on topics you'd like to } \\
\text { learn } \\
\text { - Use the tools best suited } \\
\text { to your learning styles }\end{array}$ \\
\hline Designed around the learner & $\begin{array}{l}\text { Higher Maintenance or } \\
\text { Retention: } \\
\text { The retention of online } \\
\text { classroom is better than } \\
\text { those of traditional } \\
\text { classroom because the } \\
\text { varieties of delivery } \\
\text { methods are used to reach } \\
\text { different types of learners }\end{array}$ \\
\hline Bridging & Broader Collaboration: \\
\hline
\end{tabular}


Volume 72-No.7, May 2013

\begin{tabular}{|c|c|}
\hline $\begin{array}{l}\text { geographical barriers and } \\
\text { narrow or limited education } \\
\text { systems for opening up } \\
\text { broader education options. }\end{array}$ & $\begin{array}{l}\text { Technology tools make } \\
\text { relationship among } \\
\text { students much easier even } \\
\text { in some cases learners } \\
\text { don't have to be face-to- } \\
\text { face. }\end{array}$ \\
\hline $\begin{array}{l}\text { All time or } 24 / 7 \text { accessibility } \\
\text { makes scheduling easy and } \\
\text { permits a greater number of } \\
\text { people to attend classes }\end{array}$ & \multirow{10}{*}{$\begin{array}{l}\text { Global Opportunities: } \\
\text { It gives the chance to the } \\
\text { learners to online } \\
\text { resources that they never } \\
\text { see in traditional } \\
\text { classrooms. The } \\
\text { technologies utilized give } \\
\text { online instructional } \\
\text { designers the ability to } \\
\text { construct in tools that take } \\
\text { the learners to resources } \\
\text { they may. }\end{array}$} \\
\hline $\begin{array}{l}\text { Learning can happen } \\
\text { precisely when needed } \\
\text { which is called on-demand } \\
\text { access. }\end{array}$ & \\
\hline $\begin{array}{l}\text { Travel time and related costs } \\
\text { are reduced or eliminated. }\end{array}$ & \\
\hline $\begin{array}{l}\text { Overall student costs such as } \\
\text { tuition, residence, food, child } \\
\text { care are frequently less. }\end{array}$ & \\
\hline $\begin{array}{l}\text { Training cost, supply cost, } \\
\text { cost for providers are also } \\
\text { potentially less. }\end{array}$ & \\
\hline $\begin{array}{l}\text { Promotes better student } \\
\text { interaction and collaboration }\end{array}$ & \\
\hline $\begin{array}{lrr}\text { Fosters } & \text { greater } & \text { contact } \\
\text { between } & \text { students } & \text { and } \\
\text { instructors } & & \\
\end{array}$ & \\
\hline $\begin{array}{l}\text { Improves knowledge and } \\
\text { skills related to computer } \\
\text { and Internet }\end{array}$ & \\
\hline $\begin{array}{l}\text { Represents and draws upon } \\
\text { ancient and famous } \\
\text { pedagogical principles }\end{array}$ & \\
\hline $\begin{array}{l}\text { Has the interest and attention } \\
\text { of renowned university in the } \\
\text { world having online degrees, } \\
\text { certificates, and individual } \\
\text { courses }\end{array}$ & \\
\hline \multicolumn{2}{|c|}{ Major Entities } \\
\hline $\begin{array}{l}\text { Students: } \\
\text { - } \quad \text { Take online course } \\
\text { - } \quad \text { Take exams, quiz } \\
\text { - Send feedback } \\
\text { - } \quad \text { Send homework, } \\
\text { projects } \\
\text { - } \quad \text { Send online surveys }\end{array}$ & $\begin{array}{l}\text { Teachers: } \\
\text { - Deal with content } \\
\text { management } \\
\text { - Prepare tests, quizzes, } \\
\text { assignments } \\
\text { - Deliver } \\
\text { presentations courses, } \\
\text { - Assess tests, homework, } \\
\text { projects taken by } \\
\text { students } \\
\text { - Send feedback } \\
\text { - Communicate with } \\
\text { students }\end{array}$ \\
\hline
\end{tabular}

\section{BENEFITS, RISKS AND LIMITATION OF CLOUD COMPUTING IN' $E$ - LEARNING AS A SERVICE' BASED EDUCATION SYSTEM}

Cloud computing has an important place in total education system especially in e-learning system in that the appropriate use of CC tools can enhance engagement among students, educators, and researchers in a cost effective manner. By using $\mathrm{CC}$ infrastructures educational institutes and systems can contemplate more on teaching and research activities rather than on complex information technology configuration and software systems management. Complexity can be reduced and security can be increased with $\mathrm{CC}$ applications in education systems. Cloud solutions can be utilized to maintain supportive, cooperative and socially oriented learning, using computer technologies to support collaborative or joint methods of instruction. CC offers many services and benefits to e-learning solutions by providing the infrastructure, platform and applications such as educational services directly through cloud providers and by using virtualization, centralized data storage, security, efficiency, scalability and facilities for data access monitoring. Using CC technology educational institutions can cooperate with each other and create a widespread virtual there by reducing the expenses and the man power required to install a well-equipped class room, computing and research laboratories. Cloud computing becomes an important requirement for many educational institutions having a significant impact on the teaching and learning environment because of some unavoidable reasons like costs increase, institutional performance, competition. The challenges that are faced by higher education institutes are the ever changing environment. Economic issues and the requirement to reduce the operating cost to remain competitive. CC provides services that are easily configured, deployed, dynamically-scaled, and managed in virtualized environments. It endows with the foundation and capabilities for the dynamic infrastructure through a consumption and delivery model for services in which the user sees only the service and has no need to know anything about the technology or implementation. The use of $\mathrm{CC}$ in education system must be analyzed from the benefits, limitations, risks and security points of view as shown in Table 2 which will help the decision makers to take decision that must take into account the real needs and be aligned with the education institute as well as university strategy [13]-[21]. 
Volume 72-No.7, May 2013

Table 2: Cloud computing characteristics: benefits, limitations, security and risks towards e-learning as a service system

\begin{tabular}{|c|c|c|}
\hline Benefits & Limitations & Security and Risks \\
\hline $\begin{array}{l}\text { Access to } \\
\text { application } \\
\text { from } \\
\text { anywhere }\end{array}$ & $\begin{array}{l}\text { Not all } \\
\text { applications run } \\
\text { in cloud }\end{array}$ & $\begin{array}{l}\text { The main risks in } \\
\text { cloud computing are } \\
\text { security and data } \\
\text { protection risks. }\end{array}$ \\
\hline $\begin{array}{l}\text { Support for } \\
\text { teaching and } \\
\text { learning }\end{array}$ & $\begin{array}{l}\text { Risks related to } \\
\text { data protection } \\
\text { and security and } \\
\text { accounts } \\
\text { management }\end{array}$ & \multirow{8}{*}{ 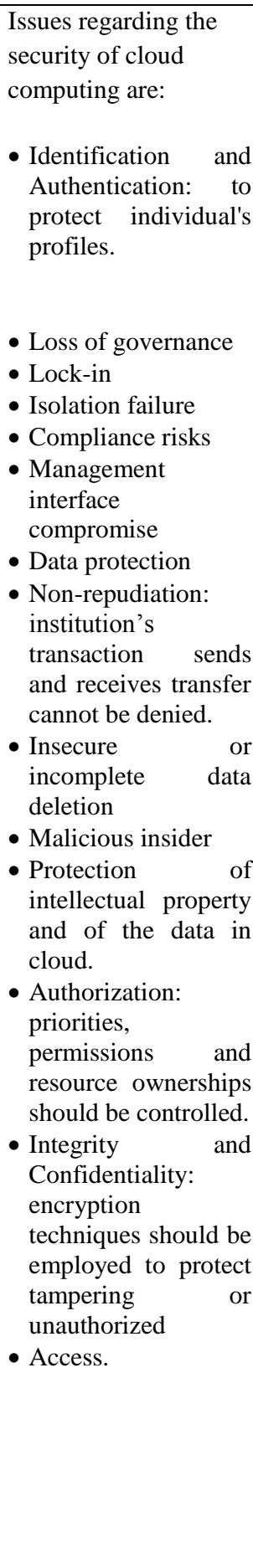 } \\
\hline $\begin{array}{l}\text { Software } \\
\text { free or pay } \\
\text { per use }\end{array}$ & $\begin{array}{l}\text { Organizational } \\
\text { support }\end{array}$ & \\
\hline $\begin{array}{l}24 \text { hours } \\
\text { access to } \\
\text { infrastructur } \\
\text { e and } \\
\text { content }\end{array}$ & $\begin{array}{l}\text { Dissemination } \\
\text { politics, } \\
\text { intellectual } \\
\text { property }\end{array}$ & \\
\hline $\begin{array}{l}\text { Opening to } \\
\text { business } \\
\text { environment } \\
\text { and } \\
\text { advanced } \\
\text { research }\end{array}$ & $\begin{array}{l}\text { Security and } \\
\text { protection of } \\
\text { sensitive data }\end{array}$ & \\
\hline $\begin{array}{l}\text { Protection of } \\
\text { the } \\
\text { environment } \\
\text { by using } \\
\text { green } \\
\text { technologies }\end{array}$ & $\begin{array}{l}\text { Maturity of } \\
\text { solutions }\end{array}$ & \\
\hline $\begin{array}{l}\text { Increased } \\
\text { openness of } \\
\text { students to } \\
\text { new } \\
\text { technologies }\end{array}$ & $\begin{array}{l}\text { Lack of } \\
\text { confidence }\end{array}$ & \\
\hline $\begin{array}{l}\text { Increasing } \\
\text { functional } \\
\text { capabilities }\end{array}$ & $\begin{array}{l}\text { Standards } \\
\text { adherence }\end{array}$ & \\
\hline $\begin{array}{l}\text { Offline } \\
\text { usage with } \\
\text { further } \\
\text { synchronizat } \\
\text { ion } \\
\text { opportunities }\end{array}$ & $\begin{array}{l}\text { Speed/lack of } \\
\text { Internet can } \\
\text { affect work } \\
\text { methods }\end{array}$ & \\
\hline
\end{tabular}

\begin{tabular}{|l}
\hline Some other benefits: User Level: \\
- Increasing availability and integrity of data and \\
applications for administrators, teachers and others \\
- Increasing mobility for students, faculty and staff \\
- Reducing local application and system resource \\
footprint \\
- Increasing application and computing performance \\
- Increasing server and data storage capacity \\
IT Department: \\
- Cost reduction \\
- Centralized management of data and Applications \\
- Standardization of applications and Processes \\
- Increased flexibility for resource allocation \\
- Higher utilization of resources \\
- Rapid provisioning of software, resources and \\
management of data \\
- Reduced burden of software version control \\
- Increase in available funds for innovation
\end{tabular}

\section{CLOUD COMPUTING TAXONOMY TOWARDS BUILDING A UNIFIED MODEL}

Cloud computing is a multidimensional computing model based on Internet technology to ensure that users can simply use the computing effectively and efficiently resources on demand [22]. Cloud computing consists of three layers, these are: Infrastructure as a service (IaaS), Platform as a service (PaaS), and Software as a service (SaaS) layer. Where IaaS is innovation or fundamental model, PaaS is developing applications model and SaaS is using applications or applications delivery model. One of the major concerns of CC is to provide services are accessible anywhere in the world with the cloud appearing as a single point of access for all the computing needs of consumers at affordable cost, elastic scalability, high performance and security. This section details an extended taxonomy that illustrates various aspects of CC. One of the major aspects of CC is its mode. Modes of CC can be defined by four major categories. These are: public cloud, private cloud, hybrid cloud and community cloud. Cloud adoption and implementations rate in various regions increase dramatically every year that encourage the academia and researchers to think about the advancements of CS. Beside the major clouds mode of $\mathrm{CC}$ discussed before there are some other new trends highlighted in year 2011-2012, such as big data cloud, business cloud, mobile cloud, gamification cloud, medical cloud, education cloud, and government cloud [23][27]. Clouds mode and its recent advancements are shown in Figure 2 [1].

\section{Major Clouds Mode}

1) Public Cloud: in public cloud the cloud infrastructure and resources are made available to the general public or a large industry group via web applications and services from third party organizations who share and selling resources and services.

2) Private Cloud: The cloud infrastructure, such as data and processes are processed and operated within single organization.

3) Hybrid Cloud: Two or more clouds are combined together to form a unique cloud infrastructure enabling data and application portability.

4) Community Cloud: The cloud infrastructure and resources are shared to for specific community. The shared concerns mission, security requirements, policy, or compliance considerations. 


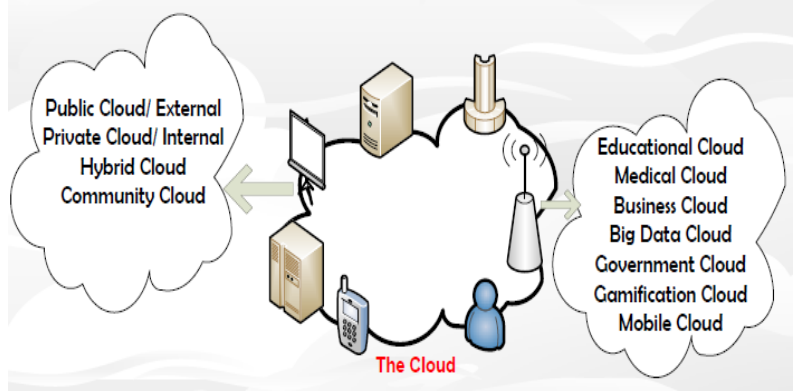

Figure 2: Clouds mode

\section{Newly Proposed Mode}

1) Big Data Cloud: The big data cloud enables an economical way to extract value from very large volumes of a wide variety of data by high-velocity capture, discovery, transformation, and analysis.

2) Business Cloud: Business-context clouds are projected to bring into line openly with the industry verticals and offer unique solutions addressing the specific business and technical challenges in the individual sectors, such as education, healthcare and financial services.

3) Mobile Cloud: Mobile applications will persist to develop with the communal facilities and pioneering mobility devices, which will drive the accelerated progress of cloud computing to empower the users and consumerization: anybody, anywhere, anytime, and any device. The mobile cloud will push many organizations to rethink their business models.

4) Gamification Cloud: The gamification cloud makes technology edutainment, guide a participant with a path to mastery and autonomy, encourage users to involve in desired behaviors, and make use of humans' psychological predisposition to engage in gaming.

5) Educational Cloud: It deals with the tasks of cloud computing technology to improve education and learning methodologies.

6) Medical cloud: A new cloud base platform allows securing access to medical records. The idea is to speed up communication between patients, consultants and general practitioners through accessing files through the internet.

7) Government cloud: In order to increase efficiency and reducing cost the Governments around the world is actively looking into cloud computing systems and services.

The major CC layers, their major functionalities, and available vendors providing cloud services to education system are illustrated in Table 3. Depending on the requirements, the customers can choose one or more services provided. The customers are renting or simply accessing the needed processing capacity from the data center using the client applications. The quality of the service becomes a crucial factor of the cloud computing success. Cloud computing is highly scalable and creates virtualized resources that can be made available to users [28].

\section{PROPOSED UNIFIED CLOUD COMPUTING MODEL FOR EDUCATION SYSTEM}

The edges of cost and effort in education system are always increasing. E-learning is a center for inclusive knowledge societies to sharing, exchange and promote low cost or free access of knowledge and skills with minimal effort. The major advantages derived from the proposed model are:

a) Potential and powerful computing and storage capacity: cloud enabled e-learning as a service based education system model detects the computing and data in a huge number of distributed or internet computers, the ocean of clouds in the tens of thousands of computers to provide potential and powerful computing power and huge data storage space, therefore puts the cloud as a service available to students via the Internet technology

b) High availability: this system must provide a higher quality of service through the integration of mass storage and highperformance computing power. Cloud computing does not affect the regular operation of the system; it can spontaneously detect the node failure and exclude it.

c) High security: in the cloud computing model, data is storied intensively. Depending and relying on one or more data center, the managers manage the amalgamated or unified data, distribute or allocate the resources, equilibrium or balance load, organize or deploy the software, regulate, manage or control security, and do the consistent or reliable real time monitoring, in this way guarantee the clients or users', for our case students-teachers data security to the greatest possible degree.

d) Virtualization: CC system is managed, expensed, migrated, and backup through virtualization platform. It put the underlying hardware, containing servers, storage and networking equipment, complete virtualization, in order to build a resources pool of shared, distributed on-demand. 


\begin{tabular}{|c|c|c|}
\hline $\begin{array}{l}\text { Cloud } \\
\text { Layers }\end{array}$ & $\begin{array}{l}\text { Maintenance } \\
\text { and Support }\end{array}$ & Available Vendors \\
\hline $\begin{array}{l}\text { IaaS : } \\
\text { Infrastructu } \\
\text { re as a } \\
\text { Service }\end{array}$ & $\begin{array}{l}\text { Specific: } \\
\text { Virtualization, } \\
\text { Servers, Storage, } \\
\text { Networking } \\
\text { General: Virtual } \\
\text { Machine, Load } \\
\text { balancers, raw } \\
\text { (block) and file- } \\
\text { based storage, } \\
\text { firewalls }\end{array}$ & $\begin{array}{l}\text { Amazon EC2 Azure } \\
\text { Services , Platform, } \\
\text { DynDNS, Google } \\
\text { Compute Engine, HP } \\
\text { Cloud, iland, Joyent, } \\
\text { LeaseWeb, Linode, } \\
\text { NaviSite, Oracle } \\
\text { Infrastructure as a } \\
\text { Service, Rackspace } \\
\text { Open Cloud, } \\
\text { ReadySpace Cloud } \\
\text { Services, ReliaCloud, } \\
\text { SAVVIS, SingleHop, } \\
\text { and Terremark }\end{array}$ \\
\hline $\begin{array}{l}\text { PaaS: } \\
\text { Platform as } \\
\text { a Service }\end{array}$ & $\begin{array}{l}\text { Specific: } \\
\text { Runtime, } \\
\text { Middleware, } \\
\text { Operating System } \\
\text { (OS), } \\
\text { Virtualization, } \\
\text { Servers, Storage, } \\
\text { Networking } \\
\text { General: } \\
\text { programming } \\
\text { language } \\
\text { execution } \\
\text { environment, } \\
\text { database, web } \\
\text { server, } \\
\text { development } \\
\text { tools }\end{array}$ & $\begin{array}{lr}\text { AWS } & \text { Elastic } \\
\text { Beanstal, } & \text { Cloud } \\
\text { Foundry, } & \text { Heroku, } \\
\text { Force.com, } & \\
\text { EngineYard, Mendix, } & \\
\text { OpenShift, } & \text { Google } \\
\text { App } & \text { Engine, } \\
\text { Windows } & \text { Azure } \\
\text { Cloud Services and } \\
\text { OrangeScape. }\end{array}$ \\
\hline $\begin{array}{l}\text { SaaS: } \\
\text { Software as } \\
\text { a Service }\end{array}$ & $\begin{array}{l}\text { Specific: } \\
\text { Application, } \\
\text { Data, Runtime, } \\
\text { Middleware, } \\
\text { Operating System } \\
\text { (OS), } \\
\text { Virtualization, } \\
\text { Servers, Storage, } \\
\text { Networking } \\
\text { General: CRM, } \\
\text { Email, virtual } \\
\text { desktop, } \\
\text { communication, } \\
\text { games }\end{array}$ & $\begin{array}{lr}\text { Google } & \text { Apps, } \\
\text { Microsoft } & \text { Office, } \\
365, \quad \text { Onlive, GT } \\
\text { Nexus, } \\
\text { Casengo } \\
\text { TradeCard. }\end{array}$ \\
\hline
\end{tabular}

Table 3: Major functionalities of cloud computing layers e) The foremost benefit of the proposed unified CC model is that it aims at providing easy access to costly software running on high performance processors to rural students at institutions which lack considerable facilities. Substantial speculation and investment would be required to implement this architecture, but the benefits would easily justify the cost. This advantage can be visualized from the following Figure 3 which illustrate the connectivity tier of the proposed architecture must be managed by web collaboration services.

f) In the generic e- learning model, teachers allot teaching tasks, conduct regular lectures, or train students' skills. The students attend the online self-governing learning act and accommodating learning sessions, or complete teachers' assignments. But in the proposed unified model teachers also answer students' questions and offer essential teaching to major and difficult points. Teachers can also use multimedia technology to augmenting teaching contents. Students work out their own learning strategies, defining learning methods independently. They conduct on-line self-directed learning when they study each unit, finish its test via Internet and do some statistics to the test and exam results. Teachers also embolden students to collaborate with each other to finish simple learning tasks or complex group-based projects. Through supportive and cooperative learning, students cannot simply obtain knowledge, their team spirit and coordination will also be raised, skills in dealing with people will be improved and abilities to express themselves will be enhanced. Hence the learning and teaching will be more collaborative; interactive which is the request of the new era. The interactive mode of the proposed unified CC model is furnished in the Figure 4 and Figure 5.

The fundamental factors interests in CC are rapid decrease in hardware cost, increase in computing power, increase in storage capacity, rising data size in scientific instrumentationinternet publishing-archiving services, wide-spread implementation of services computing [29].

To reduce university's IT complexity, maintenance and security hazards, and cost the trend $\mathrm{CC}$ is to replacing applications programs and software traditionally installed on campus computers with the same delivered distributed via the net or internet [30]. It also reduces many of the time-related constrictions for students, making learning tools accessible for a larger number of students [31]. There are many benefits of using $\mathrm{CC}$ in educational institute and system like e-learning, such as: universities based technology infrastructures for research advancements, universities can coup up with evergrowing resource requirements and energy costs, helps the students and help to manage projects and massive workloads in new and different ways, the universities or education communalities will can easily and better understand the value of new technologies [32]. CC permits students and teachers to use applications without installing them on their computers and allows access to saved files from any computer with an Internet connection [33].

In this research paper the author emphasized and highlighted a new model for educational area by introducing the cloud computing in order to increase the scalability, flexibility and availability of e-learning systems. The author has studied, analyzed and appraised the outmoded e-learning networking model, with its advances and issues, and the possibility to move the e-learning system out of schools-collegesuniversities, inside a $\mathrm{CC}$ infrastructure and platform that is a cloud system. The roles of different layers of $\mathrm{CC}$ in respect to 
education process and responsibilities from both vendors and clients' points of view are illustrated in Figure 6.

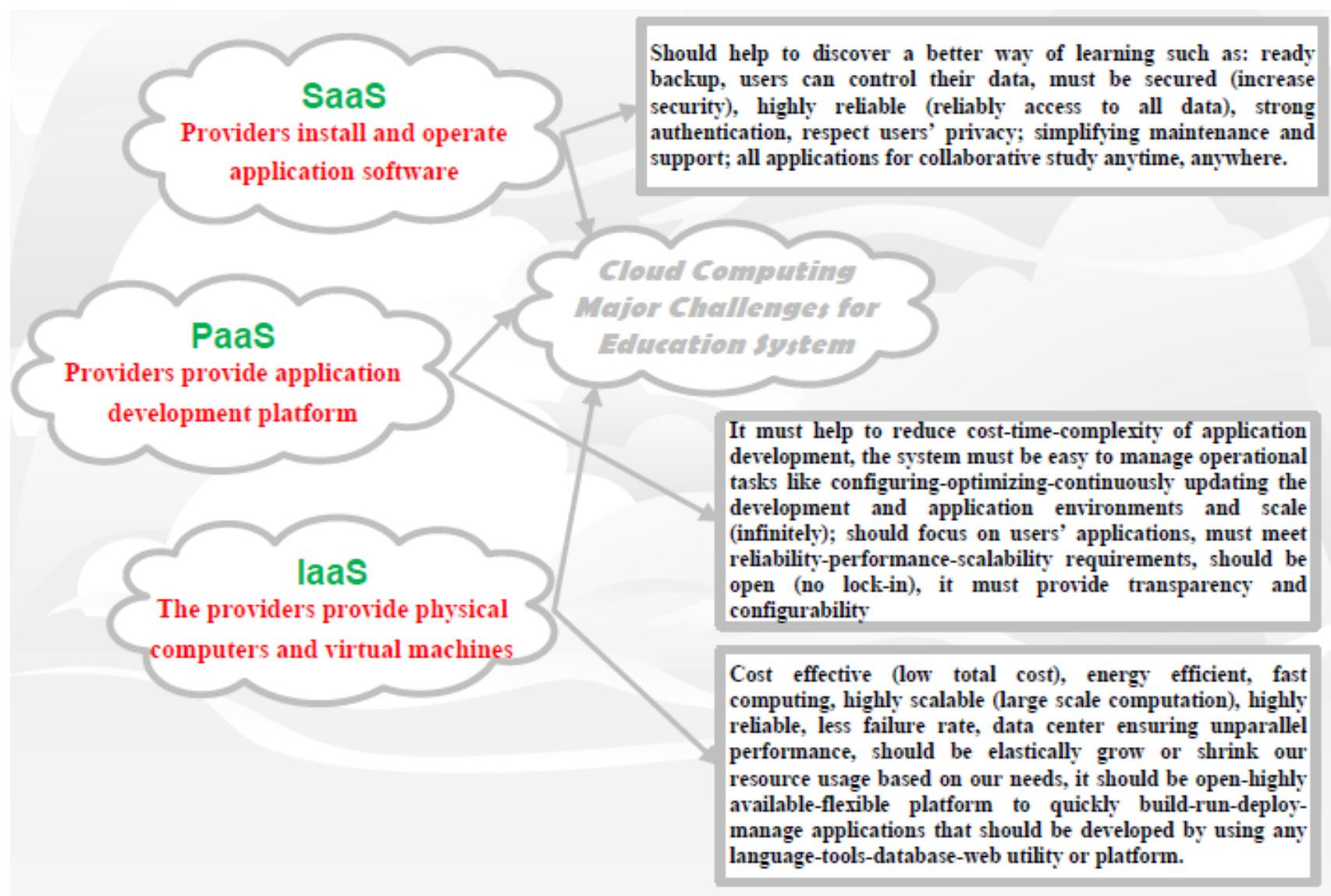

Figure 3: Connectivity tier of the proposed unified $\mathrm{CC}$ model

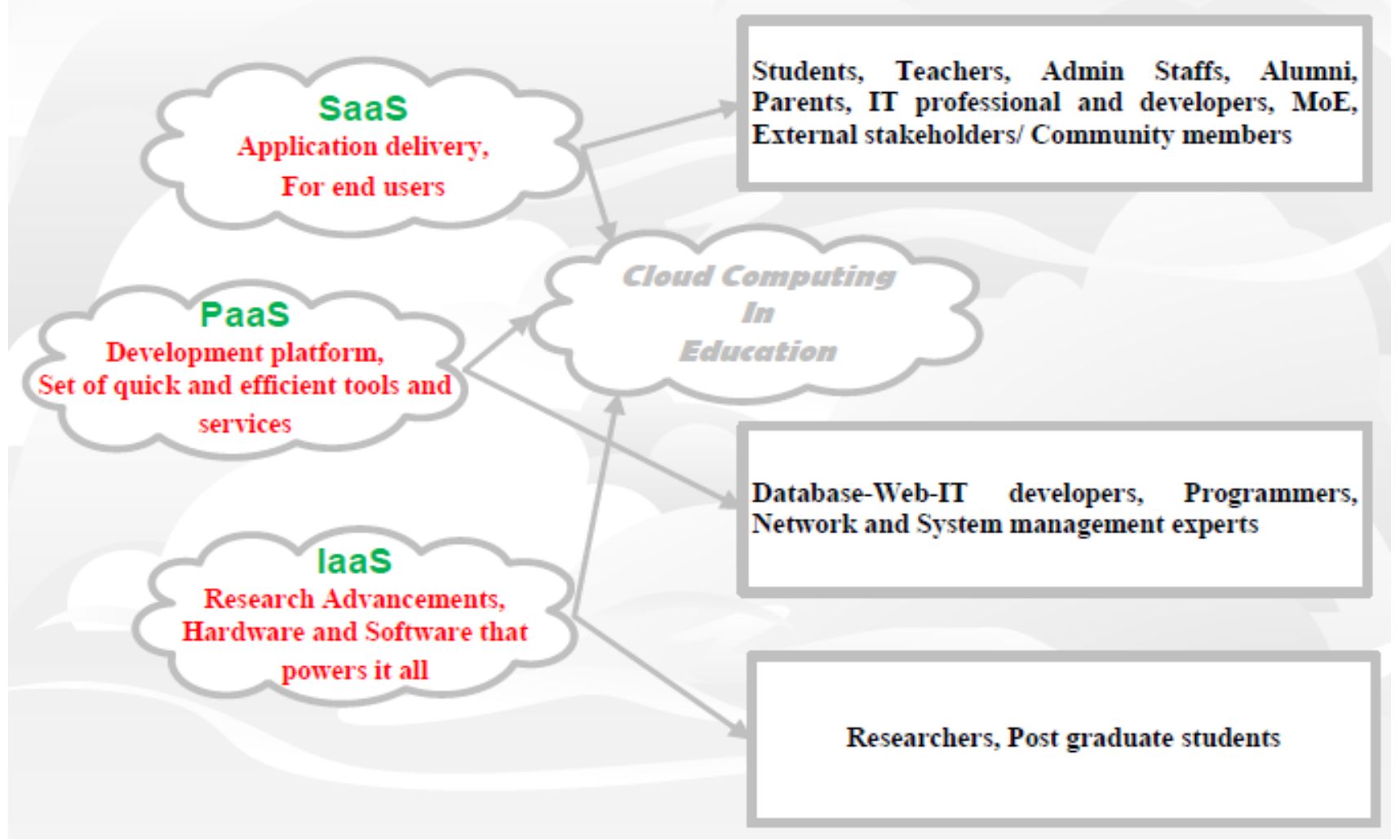

Figure 4: The stakeholders of the proposed unified CC model 


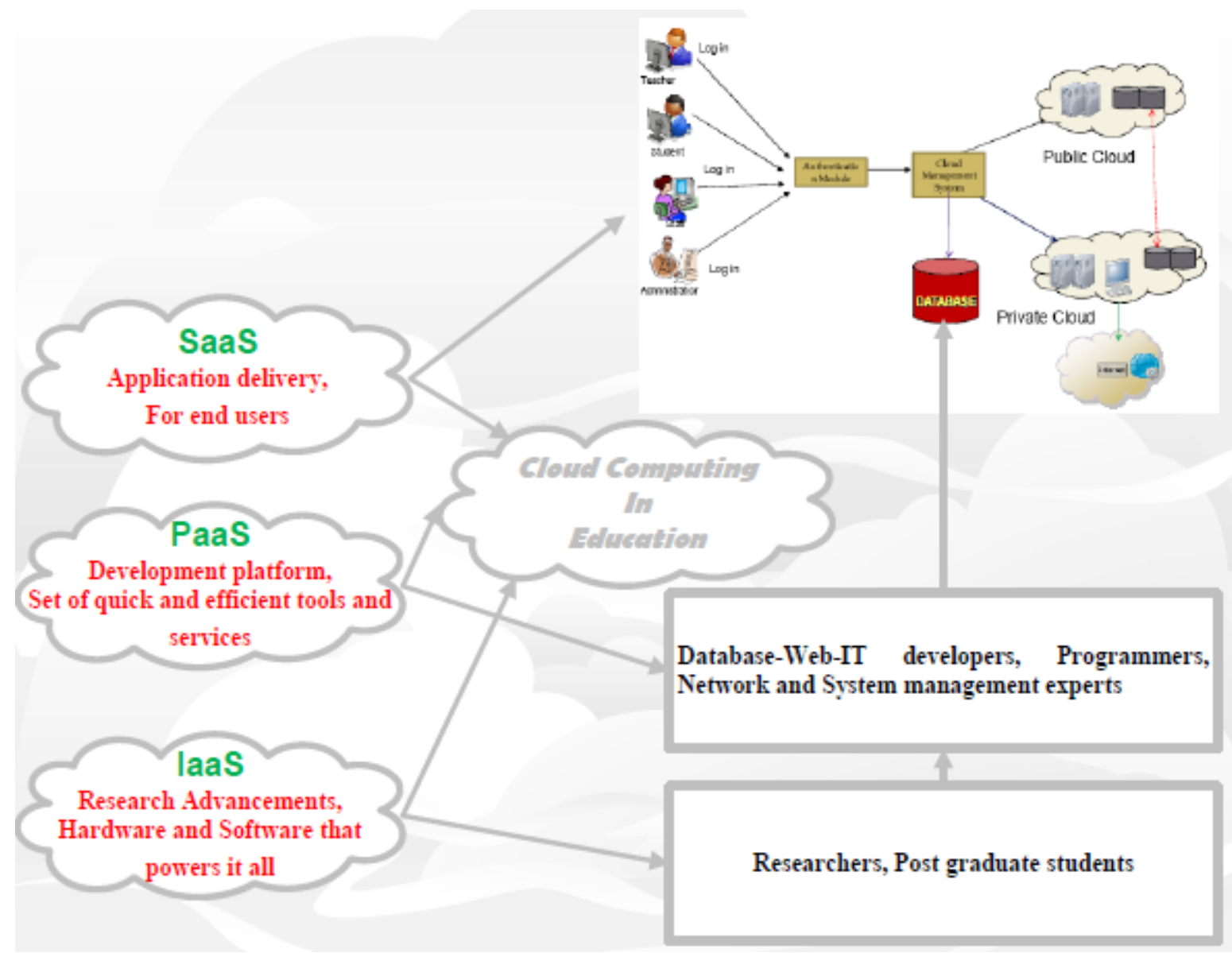

Figure 5: The interactive mode of the proposed unified CC model 


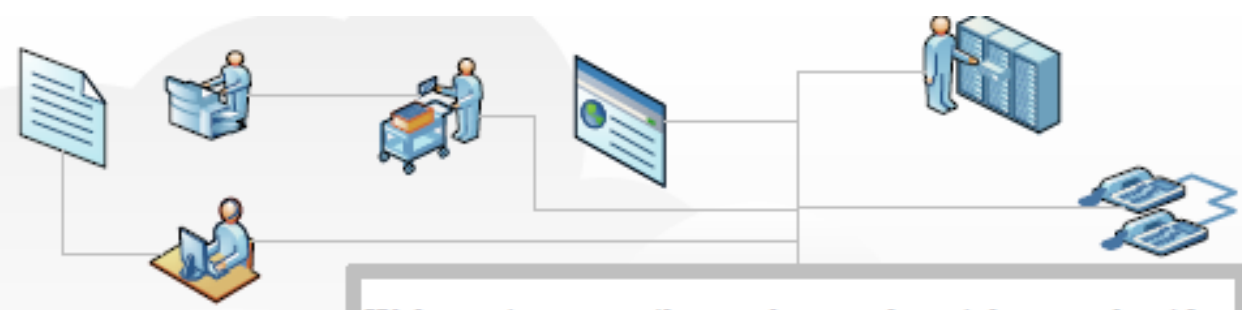

Web services: e-mail, search, portal, social network, video conference, e-library, e-portfolios, OS, antivirus $\mathrm{S} / \mathrm{Ws}$, application $\mathrm{S} / \mathrm{Ws}, \mathrm{H} / \mathrm{W}$ s: $\mathrm{PCs}$, servers; content access and

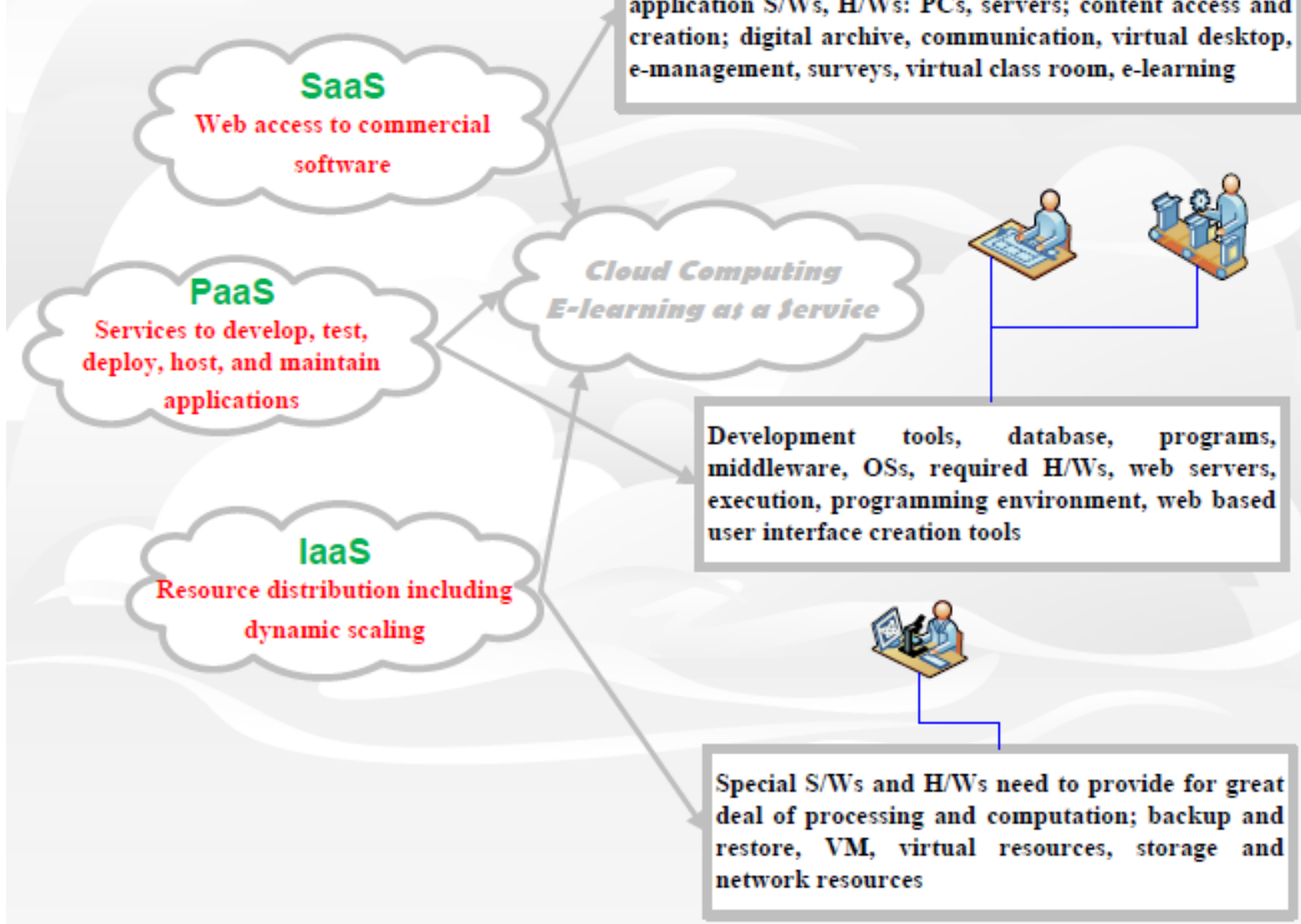

Figure 6: The roles of different layers of $\mathrm{CC}$ in respect to education process and responsibilities

The education institutions will be accountable for the education process, content management and delivery, and the vendors take care of system construction, maintenance, development and management. The e-learning system can be scaled, both horizontally and vertically, and the educational organization is charged according to the number of used servers that depends on the number of students. A services catalog can include education specific user services including e-assessment service for managing student assessments, grade book, roster, lesson plan, classroom management services for teachers, content management services that teachers use to assign curriculum content to students and that students use to access the assigned content, an online community service that teachers use to interact with peers and share lesson plans, a professional development service that teachers use to manage their career development path and become more proficient on the use of technology in the classroom. The services catalog can also include additional user services that are accessible from the cloud but are not directly related to the delivery of education. These additional services might include a fundraising service to track contribution and fundraising events, a university asset tracking service to track equipment and supplies, a university bulletin service to inform parents and the entire community of university activities. A generic CC service model that supports a total education system is illustrated in figure 7 .

\section{ADVANTAGES OF USING THE PROPOSED MODEL IN EDUCATION SECTOR}

The advantages of using this unified cloud model in educational institutions or systems for any learning process are considered in the non-functional, economic and technological areas.

Non-functional Features: It is an important fundamental feature of clouds and defines the potential of the primary infrastructure to adapt to changes potentially non-functional requirements like application supported data size, number of simultaneous users etc. 


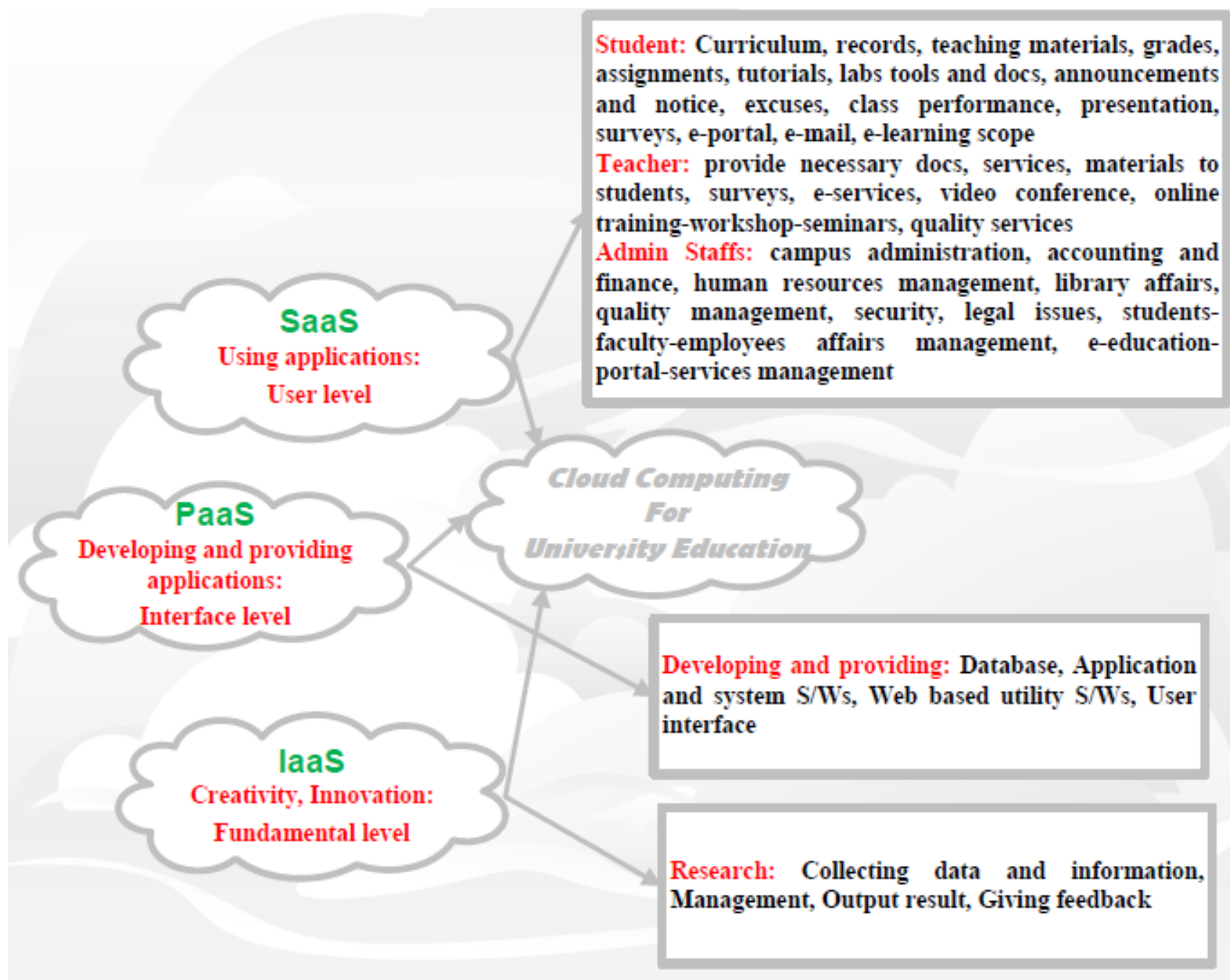

Figure 7: A unified and generic cloud computing service model for education system

Economic Aspect: Cost reduction is one of the first concerns to build up a cloud system that can adapt to changing consumer behavior and reduce cost for infrastructure maintenance and acquisition. Scalability and Pay per Use are essential aspects of this issue.

Technical aspects: The main technological challenges that can be identified and that are commonly associated with cloud systems are illustrated in Table 4. 
Table 4: Various aspects of cloud computing in education sector

\begin{tabular}{|c|c|c|}
\hline $\begin{array}{c}\text { Non Functional } \\
\text { Aspects }\end{array}$ & $\begin{array}{l}\text { Economic } \\
\text { Aspects }\end{array}$ & Technical Aspects \\
\hline 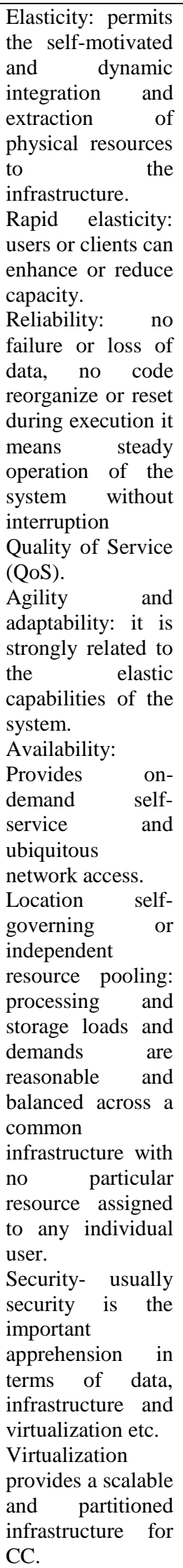 & $\begin{array}{l}\text { Pay per use: } \\
\text { relates to QoS } \\
\text { support. } \\
\text { Improved time } \\
\text { to market: } \\
\text { ensures quick } \\
\text { services with } \\
\text { little delays. } \\
\text { Return of } \\
\text { investment } \\
\text { (ROI). } \\
\text { Cost reduction } \\
\text { Going Green: } \\
\text { reducing the } \\
\text { consumption } \\
\text { of unused } \\
\text { resources, } \\
\text { reduce the } \\
\text { carbon } \\
\text { footprint. }\end{array}$ & $\begin{array}{l}\text { Data } \\
\text { administration and } \\
\text { management: deals } \\
\text { with scalability, } \\
\text { flexibility. } \\
\text { Consumers need } \\
\text { not be bothered } \\
\text { about the } \\
\text { databases. } \\
\text { Programming } \\
\text { improvements, } \\
\text { developments and } \\
\text { enhancements: the } \\
\text { developer takes } \\
\text { care about } \\
\text { scalability and } \\
\text { autonomic } \\
\text { capabilities. } \\
\text { Multi-tenancy: } \\
\text { entails huge } \\
\text { potential issues, } \\
\text { varies from data } \\
\text { protection } \\
\text { legislator issues. } \\
\text { Simplicity or ease } \\
\text { of use: cloud helps } \\
\text { hide the } \\
\text { complexity of the } \\
\text { infrastructural } \\
\text { management and } \\
\text { configuration etc. } \\
\text { Cloud makes it } \\
\text { easier for the users } \\
\text { to build up new } \\
\text { applications, as } \\
\text { well as decreases } \\
\text { the overhead for } \\
\text { controlling the } \\
\text { system. } \\
\text { Independency: Site } \\
\text { independence- } \\
\text { services of cloud } \\
\text { can be accessed } \\
\text { independently } \\
\text { without knowing } \\
\text { the physical } \\
\text { position of the user } \\
\text { and the resources. } \\
\text { Bits and Pieces or } \\
\text { Tools: usually } \\
\text { necessary } \\
\text { maintain and } \\
\text { support build or } \\
\text { development, } \\
\text { improvement, } \\
\text { adaptation } \\
\text { adjustment and } \\
\text { usage or practice } \\
\text { of cloud services } \\
\text { and supports. }\end{array}$ \\
\hline
\end{tabular}

\section{EXISTING CLOUD COMPUTING SUPPORTS IN EDUCATION SYSTEM}

The growth of educational $\mathrm{CC}$ has been incorporated by many leading information technology companies. Microsoft software and services strategy are about the power of choice-a hybrid model of resources that enables the students and researcher to move as much or as little as they want to the cloud. Google Apps education in cloud computing is available at no cost to colleges, universities and educationally focused groups. Amazon Web Service has provided the universities and institutions of all sizes with an infrastructure web services platform in the educational cloud. The IBM Cloud Academy provides an application for educational institutions that are actively integrating IBM cloud computing technologies into their infrastructures for production and technical projects. HP Cloud provides an ecosystem of thought leaders who can share best practices, ideas and technology around the design and use of cloud computing capabilities for education. Many renowned cloud providers provide services and supports for education systems are illustrated in Table 5. 
Volume 72-No.7, May 2013

Table 5: Existing cloud computing services and supports for education system

\begin{tabular}{|c|c|}
\hline $\begin{array}{l}\text { Existing Cloud } \\
\text { Computing } \\
\text { Model }\end{array}$ & Main Features and Facilities \\
\hline $\begin{array}{l}\text { Microsoft } \\
\text { Live@edu [34] }\end{array}$ & $\begin{array}{l}\text { It provides facilities and considers the } \\
\text { following needs for students, } \\
\text { researchers, staff, and faculty } \\
\text { members like: } \\
\text { - Instant Message, Email and } \\
\text { Educational Calendar } \\
\text { - Academic productivity such as } \\
\text { document sharing and creation } \\
\text { - Flexibility and collaboration } \\
\text { - On demand resources for free } \\
\text { - Identity and relationship } \\
\text { management } \\
\text { - Coordinating collaborative } \\
\text { program development projects that } \\
\text { consists of multiple departments } \\
\text { - Creating applications that can be } \\
\text { shared by many students } \\
\text { simultaneously } \\
\text { - Developing social networks or } \\
\text { communities according to grade, } \\
\text { school, or study area } \\
\text { - Porting on-premise, line-of- } \\
\text { education software to the cloud } \\
\text { - Testing Web services quickly } \\
\text { - Providing Mashups of data to meet } \\
\text { accountability and assessment } \\
\text { needs } \\
\text { - Hosting public web sites } \\
\text { - Evaluating risk and making } \\
\text { informed decisions about the use } \\
\text { of educational cloud computing. } \\
\text { - Testing and deploying large-scale } \\
\text { applications in different } \\
\text { environment } \\
\text { Features: Website Creation, File } \\
\text { sharing, Word processing and } \\
\text { presentation, Desktop sharing, } \\
\text { Resource scheduling, VOIP, etc. }\end{array}$ \\
\hline $\begin{array}{l}\text { Windows Azure } \\
{[35]}\end{array}$ & $\begin{array}{l}\text { Main components of Windows } \\
\text { Azure: } \\
\text { - Windows Azure } \\
\text { - Micosoft.NET services } \\
\text { - Live services } \\
\text { - Microsoft dynamic CRM services } \\
\text { - Microsoft SOL services }\end{array}$ \\
\hline $\begin{array}{l}\text { Google Apps } \\
\text { Education (GAE) } \\
{[36]}\end{array}$ & $\begin{array}{l}\text { Applications provided by GAE: } \\
\text { Google Mail, Google Sites, Google } \\
\text { Video, Google Calendar, Google } \\
\text { Talk, Google Docs Package. Features } \\
\text { of GAE: } \\
\text { - Support: Phone support; } 24 \text { hours } \\
\text { - Service 1: Resource scheduling } \\
\text { - Service 2: 3rd party applications } \\
\text { - Service 3: Google Video }\end{array}$ \\
\hline
\end{tabular}

\begin{tabular}{|c|c|}
\hline & $\begin{array}{l}\text { - Cost: Free } \\
\text { - Storage: Same storage space as } \\
\text { gmail.com } \\
\text { - Users: No limit }\end{array}$ \\
\hline 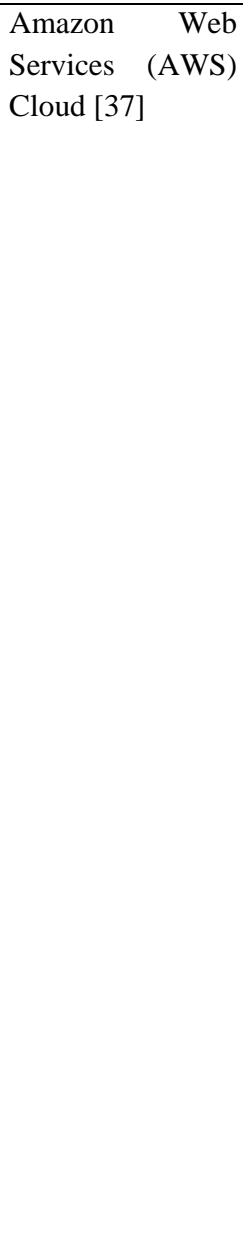 & $\begin{array}{l}\text { The AWS in education program } \\
\text { provides: } \\
\text { - Access to selected course content } \\
\text { resources. } \\
\text { - Teaching Grants for faculty based } \\
\text { on AWS. } \\
\text { - Research Grants for academic } \\
\text { researchers using AWS in their } \\
\text { work. } \\
\text { - Project Grants for student } \\
\text { organizations pursuing } \\
\text { entrepreneurial endeavors. } \\
\text { - Tutorials for students that want to } \\
\text { use AWS for self-directed learning. } \\
\text { - Solutions } \\
\text { administrators looking to use } \\
\text { educational cloud computing to } \\
\text { provide efficient and cost-effective } \\
\text { services in the institution's IT } \\
\text { infrastructure. } \\
\text { - AWS also manages the } \\
\text { infrastructure that enables students, } \\
\text { researchers and faculty to deploy } \\
\text { highly scalable and reliable IT } \\
\text { solutions. } \\
\text { Efficient and cost effective services } \\
\text { of AWS: No contracts, No hidden } \\
\text { fees, Better economics, Time } \\
\text { management, Better environment. } \\
\text { Amazon Elastic Compute Cloud } \\
\text { (Amazon EC2) supports educational } \\
\text { cloud. Features of EC2: Flexible, } \\
\text { Elastic, Completely controlled, } \\
\text { Inexpensive, Secure, Reliable. }\end{array}$ \\
\hline $\begin{array}{lr}\text { IBM } & \text { Cloud } \\
\text { Academy } & {[38]} \\
{[39][40]} & \end{array}$ & $\begin{array}{l}\text { Benefits of IBM Cloud Academy } \\
\text { members: Community access, } \\
\text { Knowledge sharing, Project support, } \\
\text { Project funding, Resources, } \\
\text { Headlights: trends to move CC } \\
\text { models and approaches. Some IBM } \\
\text { cloud education services are: IBM } \\
\text { Lotus Live collaboration, Virtual } \\
\text { Computing Lab (VCL) education } \\
\text { solution, IBM Smart Analytics } \\
\text { system, IBM Smart Business desktop } \\
\text { cloud }\end{array}$ \\
\hline $\begin{array}{l}\text { Cisco Cloud for } \\
\text { Education [41] }\end{array}$ & $\begin{array}{l}\text { Cisco Cloud is a set of capabilities } \\
\text { that brings together computing, } \\
\text { networking, and storage resources to } \\
\text { deliver a high quality cloud } \\
\text { experience to the students, educators, } \\
\text { and administrators. Its components } \\
\text { include: Cisco Unified Data Center, } \\
\text { Cisco Cloud Intelligent Network, } \\
\text { Cisco Cloud Security, Cisco } \\
\text { Collaboration Cloud Portfolio, Cisco }\end{array}$ \\
\hline
\end{tabular}




\begin{tabular}{|c|c|}
\hline & $\begin{array}{l}\text { Services. } \\
\text { Benefits of Cisco education cloud: } \\
\text { Reshaping teaching by extending } \\
\text { interactive multimedia learning } \\
\text { environments to anyone, anywhere. } \\
\text { Accelerating delivery of } \\
\text { administrative services. Simplifying } \\
\text { operations, saving time, and cutting } \\
\text { cost. } \\
\text { Reducing risk and strengthening } \\
\text { security. }\end{array}$ \\
\hline $\begin{array}{l}\text { Salesforce.com } \\
\text { Education Cloud } \\
\text { Platform [42] }\end{array}$ & 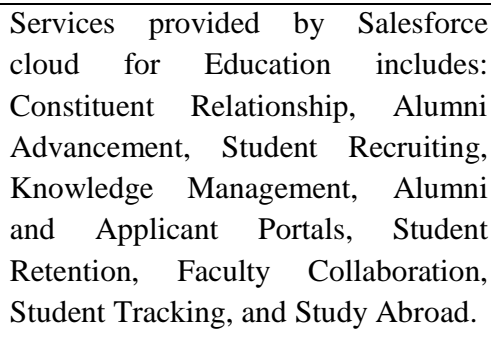 \\
\hline $\begin{array}{l}\text { ZMANDA } \\
\text { Application for } \\
\text { Education [43] }\end{array}$ & $\begin{array}{l}\text { Zmanda offers an alternative to } \\
\text { traditional storage, backup and } \\
\text { retrieve the data based on Amazon } \\
\text { Web Services and Zmanda Internet } \\
\text { Backup. Zmanda launched the } \\
\text { Amazon S3 backup solution to } \\
\text { educational organizations. }\end{array}$ \\
\hline $\begin{array}{l}\text { HP Cloud } \\
\text { Computing [44] }\end{array}$ & $\begin{array}{l}\text { With HP Cloud System, students, } \\
\text { faculty and researchers get a single, } \\
\text { seamless cloud including: } \\
\text { - Manages and delivers End-to-End } \\
\text { automated application: } \\
\text { - Unifies and controls self-service } \\
\text { portal with a built in service } \\
\text { catalog. } \\
\text { - Completes lifecycle management. } \\
\text { - Tracks the development of a cloud } \\
\text { service catalog. } \\
\text { - Supports for multiple departments } \\
\text { and clients such as students, faculty } \\
\text { and researchers. } \\
\text { - Provides scalability and one-click, } \\
\text { just in time provisioning. } \\
\text { - Innovates open standards to support } \\
\text { multiple types of applications. } \\
\text { - Provides security, privacy and } \\
\text { compliance. }\end{array}$ \\
\hline
\end{tabular}

\section{CONCLUSION AND FUTURE WORK}

Cloud computing has newly appeared as a persuasive archetype for managing and delivering services over the internet using distributed method. The enhancement of cloud computing is hastily changing the vista of information technology and eventually turning to the long-held promise of utility computing into a reality. Cloud computing can facilitate communities and nations, can transform education.
The knowledge, information, and education services can now be made available and accessible to teachers, students, researchers along with any stakeholder of education community through cloud based services that can be accessed anytime, anywhere, from any device simply, effectively with low cost and efforts. In order to compete and succeed in the present universal information society cloud computing helps the students to acquire skills and training and face the challenges of $21^{\text {st }}$ century through its education systems and services like e-learning, distance education. Present economic circumstances of many countries around the world will force different educational institutions and organizations to deem implementing a cloud solution. Many universities have already begun to adhere to this initiative, many service providers already have started to deliver their services, platforms, and infrastructure and there are proofs that indicate significant decreasing of expenses due to the implementation of cloud decision. The aim of this research was to study and analyze the overall cloud situation towards developing a unified cloud computing model which will be using within higher education to solve various learning process. Future research will include the implementation of the proposed cloud computing model to enhance and bridging the gap in education system.

\section{REFERENCES}

[1] Shah Murtaza Rashid Al Masud, "An Extended and Granular Classification of Cloud's Taxonomy and Services", International Journal of Soft Computing and Engineering, ISSN: 2231-2307, Volume-2, Issue-2, May 2012.

[2] M. Armbrust, A. Fox, R. Griffith, A. D. Joseph, R. H. Katz, A. Konwinski, G. Lee, D. A. Patterson, A. Rabki I. Stoica, and M. Zaharia, "Above the Clouds: A Berkeley View of Cloud Computing," EECS Dept., Uni. of California, Berkeley, Tech. Rep. UCB/EECS 2009-28, Feb '09.

[3] L. Qian, Z. Luo, Y. Du, and L. Guo, "Cloud computing: An overview," in CloudCom '09: Proceedings of the 1st International Conference on Cloud Computing. SpringerVerlag, 2009, pp. 626-631.

[4] G. Lin, D. Fu, J. Zhu, and G. Dasmalchi, "Cloud computing: It as a service," IT Professional, vol. 11, no. 2, pp. 10-13, 2009.

[5] P. Murray, "Enterprise grade cloud computing," in WDDM '09: Proceedings of the Third Workshop on Dependable Distributed Data Management. New York, NY, USA: ACM, 2009, pp. 1-1.

[6] A. Weiss, "Computing in the clouds," NetWorker, vol. 11, no. 4, pp. 16-25, 2007.

[7] D. Hilley, "Cloud computing: A taxonomy of platform and infrastructure-level offerings," CERCS, Georgia Institute of Technology, Tech. Rep. GIT-CERCS-09-13, April 2009.

[8] Cloud-outlook-for-2012.html: http://cloudonomic.blogspot.com/2011/12/cloud-outlookfor-2012.html\#!/2011/12/cloud-outlook-for-2012.html

[9] T. Jowitt, "Four out of five enterprises giving cloud a try," August 27, 2009. Computerworld UK, (visited: 2010, May 7). [Online]. Available: http://www.computerworlduk.com/management/ it business/services sourcing/news/index.cfm?newsId=16355

[10] R. Grossman, "The case for cloud computing," IT Professional, vol. 11 , no. 2 , pp. $23-27$, march-april 2009. 
[11] P. Mell and T. Grance, "The NIST definition of cloud computing (v15)," National Institute of Standards and Technology, Tech. Rep., 2009.

[12] A. Plesser, "CC is hyped and overblown, Forrester's Frank Gillett.....Big tech companies have 'cloud envy'," Sep '08, interview video (visited: 2010, Apr 23). [Online]. Available: http://www.beet.tv/2008/ 09/cloudcomputing.html

[13] Patterson, D. (2010). "Cloud Computing and the RAD Lab," UC Berkeley, Reliable Adaptive Distributed Systems Lab," [Online], [Retrieved October 5, 2010], http://www.mvdirona.com/jrh/TalksAndPapers/Patterson MSCloudComputingRADLab.pdf

[14] NIST, (2009). "Presentation on Effectively and Securely Using the Cloud Computing Paradigm v25," [Online], [Retrieved August 29, 2009], http://csrc.nist.gov/groups/SNS/cloudcomputing/cloudcomputing-v25.ppt

[15] Catteddu, D. \& Hogben, G. (2009). "Cloud Computing: Benefits, Risks and Recommendations for Information Security," European Network and Information Security Agency. [Online], [Retrieved October 5, 2010], http://www.enisa.europa.eu/act/rm/files/deliverables/clou d-computing-riskassessment

[16] Goldstein, P. J. (2009). "Alternative IT Sourcing Strategies: From the Campus to the Cloud," EDUCAUSE Center for Applied Research. [Online], [Retrieved October 5, 2010], http://net.educause.edu/ir/library/pdf/EKF /EKF0905.pdf

[17] Jitterbit (2009). "Five Integration Tips to Cloud Computing Success," Jitterbit, Inc. [Online], [Retrieved October 5, 2010], http://www.prweb.com/pdfdownload/2326314.pdf

[18] Luther, M. (2009). "Federated Key Management as the Basis for Secure Cloud Computing," SC Magazine

[19] Mcirvine, S. (2010). "Making Cloud Computing Safe Trust, Security, Resiliency, Availability and Complexity," IBM Corporation. [Online], [Retrieved October 5, 2010], https://www950.ibm.com/events/wwe/grp/grp004.nsf/vL ookupPDFs/Security\%20\&\%20Cloud\%20PCTY\%20\%2 0McIrvine/\$9ile/Security\%20\&\%20Cloud\%20PCTY\%2 $0 \% 20$ McIrvine.pdf

[20] SafeNet, (2010). "SafeNet Solutions Secure Cloud Computing Deployments," SafeNet, Inc, [Online], [Retrieved October 5, 2010], http://www.safenetinc. com/About_SafeNet/News_and_Media/News_and_Medi a_Items/2010/ SafeNet Solutions Secure_Cloud_Computing_Deployments.aspx

[21] Tout, S., Sverdlik, W., \& Lawver, G. (2009). "Cloud Computing and its Security in Higher Education," Proc ISECON, v26 (Washington DC): §2314, EDSIG, [Online], [Retrieved October 5, 2010] http://proc.isecon.org/2009/2314/ISECON. 2009.Tout.pdf

[22] Z. Chengyun, "Cloud Security: The security risks of cloud computing, models and strategies", Programmer, May.2010, pp.71-73.

[23] Cloud computing conference in China, May 2012, "http://www.ciecloud.org/2012/schedule03_en.html"

[24] Cloud outlook for 2012, http://cloudonomic.blogspot.com/2011/12/cloud-outlookfor 2012.html\#!/2011/12/cloud-outlook-for-2012.html.

[25] Gurdev Singh, and others, "cloud computing future solution for educational systems": http://www.ijecbs.com/January2012/29.pdf, Vol. 2 Issue 1 January 2012.
[26] Medical

cloud: technology.com/5988/the-medical-cloud/

[27] Kevin L. Jackson, "Government Cloud Computing", SOA-R Cloud Computing, Dataline, LLC.

[28] Furht,B., and Escalante,A. (2010). Handbook of Cloud Computing. New York: Springer $\mathrm{http} / / /$ searchcloudcomputing.techtarget.com/definition/pr ivate-cloud

[29] Foster, I., Zhao, Y., Raicu, I., \& Lu, S. (2008). Cloud Computing and Grid Computing 360-Degree Compared. Grid Computing Environments Workshop (pp. 1 - 10). Austin: GCE.

[30] Sasikala, S., \& Prema, S. (2010). Massive Centralized Cloud Computing (MCCC) Exploration in Higher Education. Advances in Computational Sciences and Technology , 3 (2), 111-118.

[31] Behrend, T. S., Wiebe, E. N., London, J. E., \& Johnson, E. C. (2011). Cloud computing adoption and usage in community colleges. Behaviour \& Information Technology , 30 (2), 231-240.

[32] IBM. (n.d.). Cloud Computing. Retrieved March 20, 2011, from IBM Academic Initiative https://www.ibm.com/developerworks/university/cloud/

[33] Siegle, D. (2010). Cloud Computing: A Free Technology Option to Promote Collaborative Learning. Gifted Child Today, 33 (4), 41-45.

[34] Microsoft, Cloud Computing Web Site. Cloud Computing in Education. http://www.microsoft.com/education/enus/solutions/Page s/cloud_computing.aspx

[35] Microsoft News Center. Windows Azure and the Azure Services Platform: Making Microsofts Software-plusServices Vision a http://www.microsoft.com/presspass/features/2008/oct08 /10-27pdcfeature1.mspx/

[36] Google Apps Education Edition: communication, collaboration, and security in the cloud. http://www.google.com/a/edu/

[37] Amazon Web Services (AWS) Web Site. What is AWS? A comprehensive cloud computing platform. http://aws.amazon.com/what-is-aws/

[38] IBM Academic Initiative. Cloud computing: Delivering Internet-based information and technology services in real time. https://www.ibm.com/developerworks/university/cloud/

[39] IBM Sales and Distribution, Solution Brief for Education. IBM Cloud Academy Education for a smarter planet.

ftp://ftp.software.ibm.com/common/ssi/ecm/en/eds03007 usen/EDS03007USEN.PDF

[40] http://www.ibm.com/solutions/education/cloudacademy/ us/en/

[41] http://www.cisco.com/web/strategy/education/cloud_co mputing.html

[42] Salesforce.com foundation, Higher Education. The RealTime Cloud for Higher Education http://www.salesforcefoundation.org/products/higher_ed ucation_solution/

[43] Zmanda: Zmanda Application http://www.zmanda.com/amanda-enterprise-edition.html

[44] HP cloud system http://www.hp.com/hpinfo/newsroom/press_kits/2011/E Bcloudcomputing2011/fs_Cloud_CloudSystem.pdf 